\title{
Liv Eide
}

Ph.d, universitetslektor ved Institutt for fremmedspråk

Universitetet i Bergen

\section{Forestillinger om spanskfaget: et kritisk blikk på lærebøker i spansk}

\section{Sammendrag}

Denne artikkelen retter et kritisk blikk på lcerebøker i spanskfaget, og stiller spørsmålet om de ivaretar lereplanens målsetninger om at fremmedspråksfaget skal vare et dannings- og kulturfag. Vi skal se at spanskfagets historie og utfordringer skiller seg vesentlig fra de to andre store fremmedspråkene $i$ skolen: tysk og fransk, og det er grunn til å tro at lcereboken står spesielt sterkt i spanskfaget. Videre vil vi se at det hersker en forestilling om det spanske språket som turistspråk og et språk man forbinder med populcerkultur, og at det er disse forestillingene som ofte ligger til grunn for elevenes valg av språket. Deretter presenteres en analysemodell utviklet for å analysere lcereboktekster, og generelle funn fra en undersøkelse av ni larebøker fra fire ulike lareverk $i$ spansk som er $i$ bruk $i$ den norske skolen. På bakgrunn av denne undersøkelsen vil jeg hevde at larebøkene bekrefter elevens allerede eksisterende forestillinger om faget. Larebøkenes verdensbilde utfordrer dermed ikke elevens eget verdensbilde, noe jeg mener et danningsfag bør gjøre. Ved hjelp av et konkret eksempel synliggjøres det også hvilke aspekter ved språkopplæringen elevene står i fare for å gå glipp av når undervisningen blir styrt av lcereboken. Avslutningsvis argumenterer jeg for behovet for forskning på hvordan bøkene brukes i praksis, og på leerernes egne forestillinger om spanskfaget.

\section{Innledning}

Spansk er et forholdsvis nytt fag i den norske skolen, og har etter innføringen av Kunnskapsløftet (LK06) blitt det største andre fremmedspråket, både i grunnskolen og i videregående opplæring ${ }^{1}$. Spanskfagets popularitet kan ses i sammenheng med den økte interessen for musikk og mat fra den spanskspråklige verden i Norge. Samtidig viser undersøkelser av motivasjonen som ligger bak elevers språkvalg (Doetjes \& Ryen, 2009; Lindemann, 2008), at mange velger spansk fordi de skal bruke språket på feriereiser, og fordi de har en forestilling om at språket er lett å lære. Hva skjer så når eleven møter spanskfaget i skolen? Får de utfordret eller bekreftet forestillingene sine? 
Læreboken har en sterk posisjon i fremmedspråksfaget, og er i stor grad bestemmende for undervisningspraksisen i faget (Bachmann, 2004; Europarådet, 2003; Solfjeld, 2007; Speitz \& Lindemann, 2002). For å belyse spørsmålene overfor har jeg derfor valgt å undersøke nettopp lærebøkene som blir benyttet i spanskfaget. I denne artikkelen presenterer jeg noen generelle tendenser i bøkene, og jeg har valgt å legge mest vekt på analyse av læreboktekster som omhandler Latin-Amerika. Dette mangfoldige kontinentet åpner opp for et bredt spekter av temaer som egner seg spesielt godt til å møte læreplanens danningsmål. Ifølge LK06 kan det å lære andre språk "øke vår forståelse for hvordan mennesker lever og tenker", og språk- og kulturkompetanse kan "bidra til å styrke demokratisk engasjement og medborgerskap" (Kunnskapsdepartementet 2006). Jeg vil hevde at tekster som omhandler Latin-Amerika har potensiale til å utfordre elevenes forestillinger om språket og faget.

Lærebokens rolle som bindeledd mellom læreplan (teori) og undervisning (virkelighet) gjør boken til et interessant forskningsobjekt. Vi ser her en mulig diskrepans mellom læreplanens danningsmål og elevens forestillinger om faget. I den forbindelse er det betimelig å stille følgende spørsmål: Hvilke forestillinger om spansk gjør seg gjeldende i lærebøkene? Legger bøkene, gjennom valg av tema og ved å engasjere og utfordre eleven, til rette for danning, eller er det slik at de snarere bekrefter elevens allerede eksisterende forestillinger? Hvis det siste er tilfellet, hva har det å si for spanskfaget som kultur- og danningsfag?

\section{Bakgrunn}

\section{Nytt fag, nye lærere og nye lærebøker}

Sammenlignet med tysk og fransk, som det har vært undervist i siden 1700tallet, har spansk en kort tradisjon som skolefag Norge. Vi må fram til 1970tallet for å finne spanskfagets spede begynnelse i skolen. Til gjengjeld så man for spanskfagets vedkommende en voldsom økning av etterspørsel og tilbud rundt tusenårsskiftet, ofte på bekostning av fransk- og tyskfaget. Et resultat av den store etterspørselen etter spansk som oppsto særlig etter innføringen av LK06, var en storsatsning på etter- og videreutdanning av lærere. I 2007 var nærmere tusen lærere i gang med kurs i spansk ved norske læresteder (Eide \& Johnsen, 2007). Christiansen (2006) ser med kritisk blikk på hvordan denne kompetansehevingsprosessen har funnet sted. Hun etterlyser blant annet nasjonale retningslinjer for utdanningstilbudene, og peker på mangelen på samarbeid mellom de ulike fagmiljøene. Hun hevder også at skoleeiere som har bestilt etter- og videreutdanningsoppleggene har "[...] en idé om at her skal det utdannes flest mulig lærere til lavest mulig pris” (s. 33), og peker på det faktum at flere skoler har opprettet spansktilbud før deres egne lærere engang hadde begynt sin egen utdanning i språket. Dette har igjen ført til varierende kvalitet på opplæringen, og lærere som fremdeles har lite kompetanse i språket når de 
begynner å undervise ${ }^{2}$. Etterspørselen etter spansk i skolen, og viljen til å etterkomme denne etterspørselen, førte til at lærere i andre fag måtte "omskoleres" til spansklærere; de begynte ofte uten noen form for forkunnskaper, og det å tilegne seg et nytt språk måtte gjerne gjøres ved siden av full lærerjobb.

Uten å gå nærmere inn på den store satsningen på spanskfaget ved innføringen av reformen, og problemer og utfordringer knyttet til denne, kan vi konkludere med at det rundt omkring i landet nå arbeider mange spansklærere uten mye undervisningserfaring i faget, med varierende grad av kompetanse, ofte uten et fagmiljø rundt seg, i et fag preget av mangel både på fagdidaktiske tradisjoner og forskning. Læreplanen gir heller ingen klare rammer for hva undervisningen skal inneholde. Den didaktiske friheten dette gir lærerne forutsetter, ifølge Gjørven og Trebbi (2008), en høy grad av profesjonalitet; en profesjonalitet som vi kan gå ut fra at de nye spansklærerne ennå ikke besitter. I en slik situasjon er det ikke vanskelig å forestille seg at lærerne tyr til læreboken som "anker" i sin undervisningspraksis.

Tidligere har man i spanskundervisningen i skolen benyttet seg av de samme bøkene som man brukte for voksne studenter som studerte "turistspansk" på folkeuniversitetene. Med innføringen av LK06 kom det en ny "generasjon" læreverk på markedet, som er tilpasset målgruppen. Disse læreverkene inkluderer ofte også en internettside, men det er fremdeles selve læreboken som danner utgangspunktet for undervisningen. Flere rapporter og undersøkelser bekrefter lærebokens sentrale posisjon i skolen generelt, og i fremmedspråksfagene spesielt (se blant annet Bachmann, 2004; Europarådet, 2003; Solfjeld, 2007; Speitz \& Lindemann, 2002). Rapporten Kartlegging av lceremidler og lceremiddelpraksis viser at læreboken er det sentrale læremiddelet som oftest blir brukt i forberedelsen av undervisningen, så vel som i selve undervisningen. I rapporten konkluderes det også med at læreboken oppfattes som en klar kontrakt mellom lærere, elever og foreldre om hva som er forventet kunnskap, og både lærere og elever opplever at læreboken legitimerer at undervisningen er i tråd med læreplanen (Utdanningsdirektoratet, 2005, s. 1718).

\section{Forestillinger om spansk og elevenes motivasjon for å velge faget}

Man kan hevde at det i samfunnet generelt eksisterer forestillinger om det spanske språket, og det vi for enkelthets skyld kan kalle den spanskspråklige kulturen. Leder av den norske spansklærerforeningen (ANPE) og president i det internasjonale forbundet av spansklærerforeninger (FIAPE), uttaler i et intervju i Lektorbladet at spansk, til tross for sin popularitet i skolen, fortsatt blir betraktet som mindreverdig sammenlignet med de andre språkfagene Man ser på spansk som et "feriespråk", og glemmer de spansktalende landenes rike kulturarv (Izquierdo, i Simes, 2008). Han hevder også at mange ser på spanskfaget som noe eksotisk og "motepreget” i norsk kontekst (Izquierdo, 2010). Almansa ${ }^{3}$ 
(2004) hevder at den økende interessen for spanskfaget i de skandinaviske landene delvis kan forklares med at faget representerer noe nytt i skolen, men hun vektlegger også den økende turismen de siste tiårene som årsak til språkets popularitet. I den forbindelse trekker hun fram skandinavenes lengsel etter sørlige breddegrader, og særlig det "eksotiske" Latin-Amerika, som med sin gastronomi, folklore og musikk tiltrekker turister fra nord. Jeg mener man også må legge til påvirkningen fra USA, som mange vil hevde er den fremste premissleverandøren for kultur i Norge. Jeg tenker da på oppblomstringen av det man kan kalle latinokulturen, og som vi her i Norge også har fått kjennskap til, hovedsakelig gjennom musikk og mat.

Det er, etter det jeg kjenner til, ikke gjennomført noen undersøkelser som avdekker spansklærernes syn på, eller forestillinger om, eget fag. Når det gjelder elevenes syn på faget, derimot, kan undersøkelser om deres motivasjon for å velge spansk som fremmedspråk bidra til å avdekke forestillinger om språket og faget. Disse forestillingene samsvarer i stor grad med de generelle forestillingene vi ser i samfunnet. Lindemann (2008) har undersøkt motivasjonen til 13 fremmedspråksgrupper fra fire ulike ungdomsskoler i Tromsø kommune, til sammen bortimot 300 elever. Hun konkluderer blant annet med at "[s]panskelevene velger spansk for å ha et språk som kan brukes på feriereiser" (s. 6). Dette gjelder til en viss grad også de som velger fransk, men ikke de som velger tysk, som fortrinnsvis velger faget fordi de mener det kan komme til nytte i framtidig utdannelse eller valg av yrke. De som velger spansk har gjerne flere ferieopphold i Spania bak seg, og er toppmotiverte når de tar fatt på språket, nettopp fordi de ser for seg at de skal bruke språket på nye feriereiser i nær framtid. Samtidig viser undersøkelsen at spanskelevene etter hvert opplever spansklæringen som vanskeligere og tyngre enn forventet (Lindemann, 2008, s. 8). Dette samsvarer med Fremmedspråksenterets rapport "Språkvalg på ungdomsskolen" (Doetjes \& Ryen, 2009), der det kommer fram at

[r]elativt mange, først og fremst blant de som har valgt spansk, oppgir at de reiser til et land der språket snakkes. Spesielt blant dem som har valgt spansk, er det noen som oppgir at de valgte dette språket fordi de trodde det var lett, men flere av disse oppgir også at det ikke er slik de har erfart det etter at de begynte med faget (s. 31).

For mange elever kommer det som en overraskelse at det å tilegne seg det spanske språket også krever en innsats. Lindemann (2008) hevder at "[s]panskelevene vil helst bare ha timer med underholdningspregede aktiviteter. Skal det være noe annet, må det være undervisning som foregår på norsk”, og videre at "[d]e opplever selv at faget har vært en stor skuffelse, og at det er svært lite de faktisk har lært” (s. 11).

Carrai (2009) peker på det paradokset at språkets popularitet på den ene siden kan være en stor fordel for spansklærerne, i og med at de vil starte språk 
opplæringen med toppmotiverte elever. På den andre siden kan forestillingen om at spanskfaget skal være enkelt og morsomt fort snu fordelen til en ulempe, og føre til frafall i faget.

\section{Tidligere forskning}

Til tross for lærebøkenes status i fremmedspråksfaget, er forskningen på bøkenes innhold relativ marginal. Skrunes (2010) gir et overblikk over lærebokforskningen i Norge fra 1970-tallet til i dag, men kan vise til lite forskning i fremmedspråksfagene. Når det gjelder spansk som fremmedspråk i Norge er forskningen generelt i sin spede begynnelse, og den første og hittil eneste doktorgraden ble avlagt i 2012. I avhandlingen (Eide, 2012) kombinerer jeg diskursanalytisk og tekstlingvistisk teori og metode, og tar utgangspunkt i representasjoner av Latin-Amerika i lærebøker for å analysere hvordan lærebøker ivaretar kulturaspektet og danningsperspektivet i fremmedspråksfaget.

Internasjonalt finnes det et knippe masteroppgaver og artikler som omhandler Latin-Amerika i lærebøker (se blant annet Castagnani 2009 og de la Cuesta 2009). Disse føyer seg inn i det Johnsen (1993) kaller studier av representasjoner av andre land i lærebøker, og fokuserer utelukkende på det tematiske innholdet i bøkene. Når det gjelder forholdet mellom læreplan og lærebok i spanskfaget i Norge har Nygård (2007) undersøkt i hvilken grad læreboken Mundos Nuevos 1 legger til rette for at elevene skal kunne nå kompetansemålene for hovedområdet Språk, kultur og samfunn i LK06.

I denne artikkelen kombinerer jeg disse to innfallsvinklene. Med andre ord analyserer jeg både representasjoner av Latin-Amerika og diskuterer forholdet mellom lærebok og de overordnede danningsmålene for faget, slik de kommer til uttrykk i læreplanen. I tillegg setter jeg underøkelsen inn i en større kontekst som omfatter hvilke forestillinger som finnes om spansk i det norske samfunnet generelt, og hos elever som velger spanskfaget spesielt.

\section{Metode}

Det empiriske grunnlaget for denne artikkelen er ni tekstbøker ${ }^{4}$, tilhørende fire ulike læreverk som benyttes i spanskundervisningen i den norske skolen i dag. Amigos og Tapas består av tre tekstbøker, og er beregnet på 8.-10. trinn. Vidas består av to bøker, mens Mundos Nuevos er én bok. De to sistnevnte er beregnet på elever i videregående skole. De fire læreverkene er alle tilpasset LK06, og er beregnet på spansk nivå 1 . Da de ble utgitt representerte de hvert av de fire store lærebokforlagene i Norge: Aschehoug (Mundos Nuevos), Cappelen (Vidas), Damm (Tapas) og Gyldendal (Amigos) ${ }^{5}$. Vidas og Mundos Nuevos er norske 
bøker, mens Tapas og Amigos opprinnelig er svenske, men tilrettelagt for det norske markedet. Det finnes bare tre andre læreverk beregnet på LK06, spansk nivå I på markedet ${ }^{6}$, så jeg vil hevde analysen gir et representativt bilde av lærebøkene som benyttes i spanskundervisningen i Norge.

Et læreverk består gjerne av flere komponenter: tekstbok, oppgavebok, CD og internettsider. I denne undersøkelsen tar jeg bare for meg tekstboken, da jeg vil hevde at man kan se på tekstene som "råmateriale" for det som skjer i undervisningen (Eide, 2012). Etter å ha kartlagt innholdet i de ni lærebøkene sto jeg igjen med i alt 177 konstruerte læreboktekster som omhandler LatinAmerika ${ }^{7}$. Det er dette tekstutvalget som i hovedsak danner grunnlaget for analyse og diskusjon i denne artikkelen.

Målet for analysen er å undersøke hvilke forestillinger om spansk som gjør seg gjeldende i lærebøkene. Videre vil jeg undersøke om bøkene kan engasjere og utfordre eleven, og således legger til rette for danning. For at en læreboktekst skal kunne legge til rette for danning må den etter min mening ha en affektiv eller følelsesmessig appell (jfr. Neuner 2003), temaet som formidles må egne seg til å berøre eleven, og den må kunne oppleves som dialogisk. Utgangspunktet for undersøkelsen kan dermed sammenfattes med de enkle forskningsspørsmålene hva, hvem og hvordan: Hva møter elevene i lærebøkene, hvilke temaer og kulturelle elementer fra målspråksområdet er representert? Hvem møter elevene i lærebøkene? Hvordan legger lærebokforfatteren til rette for elevens møte med målspråksområdet?

For å få svar på disse spørsmålene har jeg utviklet en analysemodell som kombinerer tekstlingvistisk metode og kategorier for analyse av det tematiske innholdet i tekstene ${ }^{8}$. Når det gjelder tekstlingvistisk metode baserer jeg meg hovedsakelig på Hallidays systemisk-funksjonelle grammatikk (se blant annet Berge et. al., 1998; Halliday, 1985), og hans teorier om språkets metafunksjoner som manifesterer seg både på ordnivå, grammatisk nivå og tekstnivå. I analysen av det tematiske innholdet i tekstene bygger jeg videre på kategoriene Risager (1991) benytter i sin analyse av generelle tendenser i europeiske lærebøker i fremmedspråk.

Når det gjelder hva som beskrives og hvem man møter, identifiserer jeg det Risager definerer som makronivå og mikronivå i teksten, henholdsvis faktakunnskap som geografi, historie og styresett, og hvilke karakterer som blir presentert og hvordan omgivelsene deres ser ut. I tillegg til disse to nivåene har jeg inkludert et mesonivå i analyseapparatet, for å fange opp aspekter ved målspråksområdet som ligger mellom individet og samfunnet, som for eksempel tradisjoner, skikker, omgangsformer og ulike kulturfenomener. For å illustrere de ulike nivåene kan man tenke seg en tekst som skal presentere Mexico. Hvis teksten utelukkende fokuserer på fakta som hovedstad, myntenhet, befolkningstall og lignende, vil den i henhold til min analysemodell bli definert som en tekst som beveger seg på makronivå. En tekst som forklarer hvordan man i Mexico feirer "De dødes dag”, for øvrig et velkjent tema fra lærebøker i spansk, vil 
defineres som en tekst som beveger seg på mesonivå. Hvis man i samme tekst møter en person som forteller om hvordan han eller hun markerer dagen, inneholder teksten informasjon både på meso- og mikronivå.

I spørsmålet om hvordan lærebokforfatteren legger til rette for elevens møte med målspråksområdet baserer jeg analysen på Martin og White (2005), som bygger videre på Hallidays teorier. De ser nærmere på hvordan en forfatter forholder seg til innholdet som blir formidlet i teksten, og til leseren han eller hun kommuniserer med. Bruk av adverb og adjektiver kan si noe om forfatterens vurdering av det som formidles i teksten. Jeg studerer også hvorvidt eller hvordan forfatteren, ved hjelp av språklige virkemidler, åpner opp for at leseren kan stille seg annerledes til det som blir formidlet i teksten, med andre ord om forfatteren legger til rette for dialog med leseren. Dette kan for eksempel skje i form av dempere eller forbehold, som adverbene muligens eller kanskje. Jeg ser videre på forholdet mellom faktatekster, det vil si deskriptive tekster som gjerne blir forbundet med nøkternhet, avstand og nøytralitet, og de mer personlige, ofte narrative tekstene som gjerne assosieres med subjektivitet og nærhet, og dermed kan ha en affektiv appell. Av de mer åpenbare språklige virkemidlene en forfatter kan benytte seg av for å engasjere og inkludere leseren finner vi direkte henvendelser i form av direktiver og ekspressiver, samt bruk av pronomenene $d u$ og vi.

\section{Resultater}

\section{Generelle funn}

Som nevnt innledningsvis åpner det latinamerikanske kontinentet opp for et bredt spekter av temaer. Videre så vi i metodedelen at et tema kan presenteres på ulike nivåer. Vanligvis vil en læreboktekst operere på flere nivåer, men jeg har i min analyse valgt å identifisere hvilket nivå det legges mest vekt på i hver enkelt tekst. 86 av de 177 tekstene har hovedvekt på mesonivå, altså det nivået som forteller noe om både samfunnet og de som bor der. Det er to temaer på mesonivå som utpeker seg: musikk og dans. I boken Tapas 2, er for eksempel et helt kapittel dedikert til latinamerikansk musikk og dans, og også i andre bøker blir disse elementene gjerne presentert som sentrale i det som blir fremstilt som en felles, latinamerikansk kultur. Forfatterne velger $\mathrm{i}$ all hovedsak to tilnærminger til temaet: enten fakta om musikkstiler som hører hjemme på kontinentet, som tango og salsa, eller presentasjoner av mer eller mindre kjente artister, som colombianske Shakira og Juanes.

Etter musikk og dans er det temaene mat og idrett som dominerer i tekstene om Latin-Amerika. Ett eksempel er teksten "Tex-mex-mat” i Vidas 2, som innledes med setningen "Har du spist burritos, nachos, enchiladas, tortillas eller

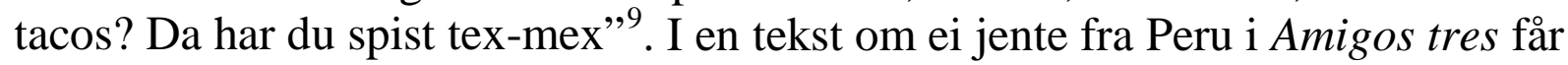
vi oppskriften på nasjonalretten ceviche, mens Mundos nuevos gir oss 
oppskriften på den nicaraguanske spesialiteten gallo pinto. I tekster som omhandler Argentina er fotball en nærmest selvsagt ingrediens, mens idrettene boksing og baseball knyttes til Cuba.

55 av tekstene har hovedvekt på makronivå, det vil si faktakunnskap om landene, eller om kontinentet som helhet. 25 av disse opererer utelukkende på makronivå. En "typisk” læreboktekst som bare presenterer tema på makronivå kan minne om tekster i oppslagsverk, der informasjon om et lands innbyggertall, myntenhet og areal blir presentert punktvis. Flagg og kartomriss av landet er gjerne inkludert som visuelle elementer i teksten. I de mer utfyllende tekstene dominerer tema som befolkningssammensetning, geografi, klima og næringsgrunnlag. I forbindelse med de to sistnevnte blir gjerne turisme nevnt. Denne informasjonen suppleres da ofte med beskrivelse av turistmålene, og informasjon om hvilke aktiviteter man kan ta del i dersom man reiser dit. Et eksempel på en slik tekst finner vi i Amigos uno, der Mexico blir presentert gjennom informasjon om geografisk beliggenhet, befolkning, språk og klima. I ett av avsnittene nevnes kystbyene Cancún og Acapulco, at dette er svært populære turistmål, og at det i nærheten av disse stedene finnes vakre øyer. På kartet over Mexico som illustrerer teksten er det tegnet inn en person som snorkler utenfor kysten av Cancún. Denne teksten er også et eksempel på en tekst som har hovedvekt på makronivå, men som i tillegg inneholder elementer av mesonivå. Teksten avsluttes med tre setninger om meksikansk mat, og nevner de typiske rettene tacos og enchiladas.

Blant de 55 tekstene med hovedvekt på makronivå finnes det også noen få eksempler på temaer knyttet til politikk og utfordringer i det latinamerikanske samfunnet. Et eksempel er teksten "Prosjekt om Colombia" i Mundos nuevos, der de spanske elevene Eva og Felipe diskuterer hvilke elementer de skal ta med i en skoleoppgave om Colombia. I tillegg til geografi, klima, næringsgrunnlag og befolkning nevnes også narkotikaproblematikken.

Spørsmålet om hvem man møter i tekstene leder oss til tekstenes mikronivå. 35 av tekstene har hovedvekt på dette nivået, det vil si at fokuset i teksten er rettet mot en eller flere personer, og deres tanker og meninger. Størstedelen av disse personene er ungdommer på alder med målgruppen for bøkene. Man møter dem stort sett bare i én tekst, og det er begrenset hva vi får vite om dem. Unntaket er gjennomgangskarakterene Clara og Eduardo i Vidas-bøkene. Clara fra Cuba er medisinstudent, og gjennom tekstene som omhandler henne får vi et innblikk i ei ung jentes hverdag på øya. Eduardo fra Ecuador er utvekslingsstudent i Bergen, og tekstene om ham inneholder en del sammenligninger mellom Norge og Ecuador.

Det er interessant å merke seg at det i tekster om Latin-Amerika er et utbredt virkemiddel å la europeiske ungdommer presentere det latinamerikanske kontinentet. Ett eksempel er teksten "Inntrykk fra Guatemala” i Vidas 1, som er utformet som et reisebrev fra ei spansk jente på reise i landet. Et annet eksempel 
er teksten "På reise i Argentina” i Tapas 3, der norske Emil sender e-post hjem om sine opplevelser.

Når det gjelder hvordan elevens møte med målspråksområdet blir tilrettelagt har jeg sett at lærebokforfatterne stort sett benytter seg av en nøytral og deskriptiv stil, men også av positivt ladede adjektiver, samt kvantifiseringer og intensiveringer, som gjør at tekstene kan minne om turistbrosjyrer. Noen av tekstene inneholder direkte henvendelser til leseren i form av spørsmål eller eksklamasjoner (som vi så i eksempelet "Tex-mex-mat” over), men disse bryter med den deskriptive stilen som ellers preger tekstene. Det finnes også mange eksempler på at lærebokforfatteren unnlater å forklare viktige begreper og fenomener, og dermed forutsetter at eleven allerede innehar denne kunnskapen. Dette vil vi se eksempler på når jeg nå går nærmere inn på eksempelet Cuba i læreboktekstene.

\section{Eksempel: Cuba}

Årsaken til at jeg velger å bruke akkurat Cuba som eksempel er at landet, med sin historie og dagens politiske situasjon, i utgangspunktet vil kunne være et ideelt utgangspunkt for å arbeide med læreplanens mål om demokratisk engasjement, og forståelse og respekt for andres levemåter ${ }^{10}$.

I de fire læreverkene jeg har analysert er det temaer knyttet til musikk og dans, som oftest salsa, som dominerer i presentasjonen av Cuba. Sport, turisme og religion er også temaer som er representert. Et par tekster omhandler Che Guevaras liv, og dermed også den cubanske revolusjonen. I noen tekster får man et "hint” om dagens situasjon på øya, som for eksempel i teksten "Leve salsaen!” i læreboken Amigos dos. Om tekstene i salsamusikken sies det her at "De handler om livet, om kjærligheten, om sjalusi, eller også om mer alvorlige temaer, som det urettferdige cubanske samfunnet”, uten at denne informasjonen blir utdypet.

I læreverket Vidas er det cubanske Clara som presenterer landet sitt. Hun er gjennomgangsfigur i begge bøkene, og leseren får et innblikk i hennes hverdagsliv, som ikke synes å skille seg nevneverdig fra en norsk ungdoms hverdag. I teksten "Kontaktannonser”, i kapittelet "Clara på nettet” i Vidas 2, møtes for eksempel Clara og venninnene hennes hjemme hos henne for å surfe på nettet etter potensielle kjærester.

Tekstene om Claras hverdagsliv i Vidas-bøkene står i kontrast til måten forfatterne av Amigos-bøkene har valgt å presentere landet. Her fokuseres det på kuriositeter fra det cubanske samfunnet, blant annet i teksten "Bilder fra Cuba" i Amigos dos. Teksten består av fem bilder som illustrerer ulike aspekter ved Cuba, med tilhørende forklarende tekst, og fremstår nærmest som en lysbildeframvisning fra en feriereise til landet. Ett av bildene viser de gamle, amerikanske bilene, som i turistbrosjyrer ofte blir fremhevet som nye "typisk" og "autentisk" ved det cubanske gatebildet. I den forklarende teksten kan vi lese at "På Cuba finnes det fremdeles biler fra 50-tallet i bruk. Bilene er 
nordamerikanske, og det finnes ikke nye reservedeler på Cuba. Reservedelene blir sendt til dem fra slektninger i USA". Her forutsetter forfatteren en god del forkunnskaper som ikke er gitt tidligere i boken, men som er nødvendige for at teksten skal gi mening for leseren. For å forstå hvorfor det er så mange nordamerikanske biler på øya må man vite at USA dominerte Cuba fram til revolusjonen i 1959, og for å forstå informasjonen om slektningene i USA som sender reservedeler, bør man ha kjennskap til handelsblokaden og det cubanske eksilsamfunnet i USA. Først da kan man oppfatte at teksten dreier seg om mer enn reservedeler til gamle biler.

Neste bilde viser en gruppe unge og eldre menn som spiller domino utendørs. Teksten lyder: "PC-er og Internett er forbudt på Cuba. I stedet er det veldig vanlig å se unge og gamle som spiller domino i gatene”. Vi ser at måten disse setningene er satt sammen på, med adverbet $i$ stedet, sidestiller bruken av PC/Internett og det å spille domino. En norsk ungdom som er vant til å bruke deler av fritiden sin på å surfe på Internett eller spille dataspill, vil gjerne trekke den konklusjonen at når ungdom på Cuba ikke får lov til å bruke datamaskin, må de ty til dominospill i stedet. På den måten reduseres forbudet mot PC og Internett til fraværet av en fritidssyssel, uten at temaer som ytringsfrihet og sensur blir berørt.

\section{Læreboken som uttrykk for forestillinger om spanskfaget}

Vi har sett at analysemodellen gir oss svar på spørsmålene om læreboktekstenes hva, hvem og hvordan. Supplert med generelle og åpenbare trekk ved lærebøkene får vi et mer utfyllende bilde av hvilke forestillinger om spanskfaget som finnes i bøkene.

De nye lærebøkenes fokus på en yngre målgruppe gjenspeiles i temaene som behandles i tekstene. Bøkenes innholdsfortegnelser gir oss et innblikk i hva elevene møter: "Venner på kafé”, "Chatting”, "Å handle klær", "Kinobesøk”, "På diskotek, flørting". Disse temaene er tydelig ment å skulle "fenge" målgruppen, ved å møte dem der de er. Her er det i stor grad snakk om dialoger som utspiller seg i en spansktalende kontekst som i enkelte tekster kan knyttes til Spania, men som i de fleste tilfellene like gjerne kunne utspilt seg i et latinamerikansk land. Tekstene skaper på denne måten et bilde av en form for felles ungdomskultur som er lik uansett land; en ungdomskultur der alle har mulighet til å gå på kafé og diskotek, og har tilgang til Internett. I en tekst i Vidas 2, der Clara og Eduardo møtes i Norge og holder et foredrag for norske spanskelever, understreker de nettopp at latinamerikansk ungdom ikke er særlig annerledes enn norske. De interesserer seg for de samme tingene: å gå ut med venner på kafé, på diskotek, på kino eller på konserter.

Min undersøkelse viser at realiakunnskapen, som hadde en sterk posisjon i fremmedspråksundervisningen på 1800-tallet, fremdeles har en sentral plass i lærebøkene. De fleste tekstene (86 av 177) har likevel fokus på mesonivå, noe som viser at lærebokforfattere i dag er mer opptatt av å formidle kunnskap om 
kulturfenomener fra målspråksområdet. Blant de mange temaene som kunne vært aktuelle, velger lærebokforfatterne ofte å presentere Latin-Amerika gjennom musikk og mat. Både tematisk og språklig legger forfatterne til rette for at elevene skal knytte disse elementene til sine egne erfaringer. Dette ser vi tydelig i teksten "Latin-Amerika" i Vidas 1, som presenterer ulike temaer fra kontinentet. Teksten er deskriptiv, med unntak av avsnittene som omtaler nettopp musikk og mat. Her finner vi direkte spørsmål til leseren: "Hvem har vel ikke hørt salsa, tango og latino-pop?”, og "Har du spist tortillas, tacos, nachos, burritos eller chili con carne?”.

I de tidligere lærebøkene i spansk, som ble brukt både i skolen og for en eldre målgruppe, er det tydelig at turisten er målgruppen. I mange tilfeller, som for eksempel i Eso sí, det mest brukte læreverket i Norge i en årrekke, følger man i de første tekstene en turist som reiser til Spania på ferie (Eide \& Johnsen, 2006). Lærebøkene i spansk som har kommet på markedet de siste årene retter seg mot et yngre publikum, men tidligere tiders læreboktradisjon knyttet til spansk som turistspråk preger fremdeles lærebøkene. Kaster man et raskt blikk på innholdsfortegnelsen i nyere læreverk som Tapas og Amigos, finner man

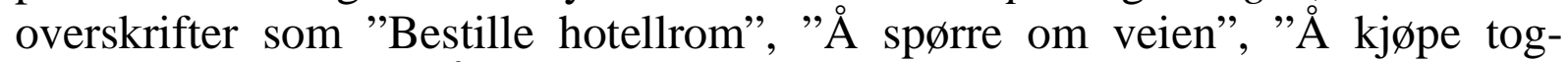
billett”, "På ferie”, "Å skrive et enkelt postkort”, og lignende. Under disse overskriftene finner man stort sett dialoger som skal fungere som modeller for språkhandlinger. Dialogene utspiller seg gjerne i et udefinert, spansktalende miljø, eller de kan knyttes til Spania gjennom henvisninger til myntenhet eller steder.

Når det gjelder tekstene som spesifikt omhandler Latin-Amerika er turistperspektivet dominerende på en annen måte enn i disse dialogene. Lærebokforfatterne fokuserer ofte på et latinamerikansk land, og beskriver det i svært positive ordelag, som i en turistbrosjyre. I teksten "Intervju med Nancy og Teresa” i Vidas 1, lar lærebokforfatterne to representanter fra Venezuela reklamere for landets høye fjell, fantastiske strender og imøtekommende befolkning. Et annet eksempel er hvordan lærebokforfatterne "fletter inn" turistperspektivet i tekster som i utgangspunktet omhandler andre temaer. Et eksempel er teksten "Dinosaurene fra Patagonia" i Amigos dos, om funn av dinosaurrester i det sørlige Argentina, der siste avsnitt er viet informasjon om hvilke aktiviteter man kan utføre som turist i området.

Det som kanskje er mest betegnende når det gjelder turistperspektivet i presentasjonen av Latin-Amerika, er likevel den hyppige bruken av tekster der europeisk ungdom reiser til et latinamerikansk land og forteller om sine opplevelser derfra. Jeg har allerede nevnt teksten om norske Emil på reise i Argentina, og spanske Ana på ferie i Guatemala. I begge tekstene er det de unge, europeiske turistene som er i fokus: Emil forteller om sine erfaringer med argentinsk kjøtt og storslått natur, men menneskene han møter på veien forblir ukjente for leseren. Ana lar seg imponere av Guatemala, men i siste linjene av reisebrevet sitt understreker hun likevel at landet ikke er et paradis. Videre 
forklarer hun at: "[f]olket, særlig urbefolkningen, har lidd mye. Men til tross for det er guatemaltekerne veldig vennlige, og de behandler meg strålende”.

\section{Diskusjon}

Resultatet av min undersøkelse viser at lærebøkene i stor grad bekrefter elevenes forestillinger om faget og språket. Særlig tekstene om Latin-Amerika er knyttet til elementer som er kjent for eleven fra før. Dette til tross for at kontinentet i utgangspunktet burde være kilde til temaer som ville kunne utfordre elevens verdensbilde. Hva har dette å si for spanskfaget som dannings- og kulturfag?

LK06 vektlegger aspekter som opplevelse av og innsikt i kulturelle forhold, kommunikasjon og deltakelse, og at språk- og kulturkompetanse skal bidra til å styrke demokratisk engasjement og medborgerskap. Innenfor hovedområdet Språk, kultur og samfunn nevnes også interesse, forståelse og toleranse (Kunnskapsdepartementet, 2006, s.2). Læreboken skal dekke læreplanens målsetninger, men ifølge Selander (1988) er det tradisjon, det vil si egenskaper ved tidligere lærebøker i faget, som er avgjørende for hvordan en lærebok blir utformet. En lærebok vil også være resultat av lærebokforfatternes syn på faget, og hva forfatterne antar er målgruppens tanker om hva en lærebok skal inneholde. Denne posisjonen i skjæringspunktet mellom fagtradisjoner, målgruppens forventninger og læreplanens føringer, gjør læreboken til et interessant forskningsobjekt når det gjelder forskning på endring, eventuelt mangel på endring, i faget. I følge Rogne (2009) behøver nemlig ikke endringsvilje på normtekstnivå, det vil blant annet si i læreplanen, nødvendigvis føre til endret praksis i faget. Det er dermed ikke slik at bruken av læreboken er en garanti for at undervisningen er i tråd med læreplanen, slik mange lærere og elever tror (jfr. Utdanningsdirektoratet, 2005).

De generelle funnene fra analysen viser nettopp at tidligere tiders tradisjon for vektlegging av faktakunnskap om målspråkslandene fremdeles preger lærebøkene. I dag kan lærere og elever imidlertid lett finne oppdatert informasjon av denne typen i andre medier. Fakta som befolkningstall og lignende hører etter min mening ikke lenger hjemme i en lærebok.

Fokuset på musikk og fritidssysler gjør at elevene stort sett bare møter det som allerede er kjent fra deres egen livsverden, og det de forventer å finne. Lærebokuniverset bekrefter dermed deres egen virkelighet. Dette funnet er i tråd med Ziehes (2001) påstand om at skolen, i et forsøk på å møte elevene der de er, har omfavnet populærkulturen, og at den har overtatt som felles referanseramme i skolen. Han hevder det er en utbredt oppfatning i skolen at bare det som er gjenkjennelig fra elevens egen, personlige verden kan aksepteres. Dette fører til at elevene ikke møter noe nytt og fremmed som kan utfordre dem. Man kan si at de ikke får anledning til å møte det de på forhånd ikke visste at de hadde interesse av å vite noe om (Ziehe, 2001). For spanskfagets vedkommende kan 
det føre til at elevene går glipp av deler av den spansktalende verdens kulturarv, som Izquierdo også påpeker (i Simes, 2008).

Det finnes selvsagt unntak i materialet jeg har analysert, det vil si tekster som tar opp temaer som kan utfordre elevens forestillinger. Som eksempel kan nevnes teksten "Barna som arbeider" i Tapas 3, der vi møter en gutt som bor på gaten og ei ung jente som arbeider for en organisasjon som hjelper fattige barn i Nicaragua. Et annet eksempel er "Mayerly drømmer om fred" i Tapas 2, om en ung colombiansk jentes tanker om framtiden. Jeg vil likevel hevde at de lærebøkene jeg har studert generelt kommer til kort når det gjelder læreplanens vektlegging av aspekter som demokratisk engasjement, interesse, forståelse og toleranse. Ved å fokusere på turisme og populærkultur inntar lærebokforfatterne en harmonisøkende tilnærming til lærestoffet (jfr. Nielsen 2003) - en tilnærming preget av overfladiskhet, og som reduserer elevenes rolle til passive observatører. Nielsen (2003) argumenterer for at man må bevege seg bort fra den utbredte oppfatning av at elevene skal oppøves i å observere og beskrive hvordan mennesker fra andre kulturer lever, og hevder at man i stedet må arbeide for at elevene skal kunne håndtere potensielle konflikter i møtet med en fremmed kultur.

Et sannsynlig resultat av en harmonisøkende tilnærming vil være det Casal (1998) kaller utstillingsvindueffekten, med andre ord en tilnærming til fremmed kultur der eleven ikke gis mulighet til å trenge igjennom til den nye kulturen, men blir stående trygt plassert på sin side av glasset. Målet må, ifølge Casal, imidlertid være å overkomme stadiet der man benytter seg av overfladiske observasjoner og sammenligninger. Dette kan man for eksempel oppnå ved at eleven gjennom tekstene får anledning til å møte mennesker fra målspråksområdet som tenker, som mener noe om viktige temaer, og som handler. På den måten kan lærebokteksten bidra til at eleven utvikler forståelse og respekt for andre levemåter, og dermed kan teksten også ivareta det allmenndannende perspektivet i fremmedspråksfaget.

Analysen av tekstenes mikronivå viser imidlertid at elevene møter få tenkende og handlende representanter for Latin-Amerika. I stedet er det turisten eleven skal identifisere seg med. Det er den europeiske turistens perspektiv og interesser som står i fokus, hennes opphold fremstilles som ukomplisert, og møtene med kontinentets innbyggere er overfladiske og uforpliktende.

Ifølge Neuner (2003) må det affektive, følelsesmessige aspektet være tilstede for at fremmedspråksopplæringen skal virke dannende. Dette aspektet dreier seg om erfaring mer enn informasjon, og er i tråd med Aases (2005) argument om at "[s]kal kunnskapen bli dannende, må den berøre elevene og utfordre dem" (s. 17). Mangelen på inkludering av leseren gjør at en stor del av tekstene i materialet fremstår som lukkede og autoritative. Den anonyme lærebokforfatterens stemme er den dominerende, og informasjon om målspråksområdet blir formidlet gjennom denne stemmen. I likhet med Fenner (2000) vil jeg argumentere for flere autentiske tekster, som vil slippe andre stemmer til og 
tilby elevene et annet perspektiv på temaene som blir presentert. Min undersøkelse omfatter ikke oppgavene knyttet til læreboktekstene, men en generell oppfatning er at disse fokuserer på grammatikk og/eller leseforståelse. Elevene blir i svært liten grad oppfordret til selv å fortolke møtet med den fremmede kulturen. Det de ser gjennom "utstillingsvinduet" er et begrenset og statisk bilde, og de blir ikke oppfordret til å stille spørsmål ved det de ser.

Eksempeltekstene som omhandler Cuba illustrerer etter min mening det elevene står i fare for å gå glipp av når lærebokforfatterne inntar en harmoniserende tilnærming til stoffet. Til tross for mulighetene Cuba i utgangspunktet gir, velger lærebokforfatterne å unngå utfordrende eller kontroversielle temaer. Vi ser at tekstene "Kontaktannonser" og "Bilder fra Cuba" gir motstridende informasjon om cubanernes tilgang til PC og Internett, men begge er talende eksempler på den harmonisøkende modellen. Den førstnevnte kan skape et inntrykk av at ungdommers hverdag på Cuba ikke skiller seg nevneverdig fra den norske, mens sistnevnte fokuserer på "ufarlige" særegenheter ved det cubanske gatebildet som man gjerne observerer som turist. Ingen av tekstene oppfordrer leseren til å stille kritiske spørsmål ved informasjonen som blir gitt.

Avslutningsvis vil jeg vende tilbake til forestillingen om at spansk er et lett språk å lære, noe elevene, ifølge flere undersøkelser, snart oppdager ikke stemmer overens med virkeligheten. Årsaken til dette kan selvsagt være at en del lærere fremdeles holder fast ved tradisjonelle metoder, samt oppfatningen av at man må kunne språkets grammatikk før man kan ta språket i bruk. Når det gjelder innholdet i læreboktekstene, derimot, vil jeg hevde at de i stor grad bygger oppunder forestillinger om det spanske språkets "letthet”. Blant de tekstene jeg har analysert finner jeg få tekster som egner seg til å utfordre eller berøre leseren, og jeg vil påstå at lærebokforfatterne på den måten undervurderer elevene. Elevene møter ikke noe nytt, de får bare bekreftet forestillingene sine om faget og språket.

\section{Konklusjon}

Vi har i denne artikkelen sett at spanskfaget står i en særstilling sammenlignet med fremmedspråksfagene tysk og fransk, da faget fremdeles har mange nye og uerfarne lærere. For disse lærerne kan læreboken være til uvurderlig hjelp og støtte i et nytt fag uten lange fagtradisjoner. Samtidig er det viktig å se lærebokens begrensninger, og være observant på de perspektivene ved fremmedspråkslæringen man står i fare for å miste når lærebøkene i så stor grad bekrefter forestillingene om et språk knyttet til turisme og populærkultur.

På bakgrunn av min analyse vil jeg hevde at lærebøker i spansk ikke legger tilstrekkelig til rette for danning. Til syvende og sist er det likevel det som skjer i klasserommet som bestemmer om faget skal virke dannende på eleven. Det er derfor behov for forskning på hvordan lærebøkene brukes i praksis. Jeg vil også 
argumentere for nødvendigheten av videre forskning på forestillinger om faget. Vi har sett hvilke forestillinger om språket og faget som gjør seg gjeldende hos elevene og i bøkene, men det ville også være interessant å undersøke spansklærernes forestillinger om sitt eget fag.

\section{Litteratur}

\section{Lærebøker}

Alves, C., Eriksson, T., Johnson, T., Noreen, M., Medina, M. \& Rodriguez, F. (2004). Tapas 1. Elevbok. Oslo: Damm.

Alves, C., Eriksson, T., Johnson, T., Noreen, M., Medina, M. \& Rodriguez, F. (2005). Tapas 2. Elevbok. Oslo: Damm.

Alves, C., Eriksson, T., Johnson, T., Noreen, M., Medina, M. \& Rodriguez, F. (2006). Tapas 3. Elevbok. Oslo: Damm.

Bugge, L. K., Halvorsen, S. \& Rovira, S. (2006). Vidas 1. Tekstbok. Oslo: Cappelen.

Bugge, L. K., Halvorsen, S. \& Rovira, S. (2007). Vidas 2. Tekstbok. Oslo: Cappelen.

Groth, B. H., Sbertoli, G., Skjær, S. \& Aass, S. (2006). Mundos nuevos 1. Libro de textos. Oslo: Aschehoug.

Riquelme, A., Salomonsen, L., Knutagård, M. S., de la Motte, A. \& Lizana, H. (2004). Amigos uno. Textos. Oslo: Gyldendal undervisning.

Riquelme, A., Salomonsen, L., Knutagård, M. S., de la Motte, A. \& Lizana, H. (2005). Amigos dos. Textos. Oslo: Gyldendal undervisning.

Riquelme, A., Salomonsen, L., Knutagård, M. S., de la Motte, A. \& Lizana, H. (2006). Amigos tres. Textos. Oslo: Gyldendal undervisning.

\section{Referanser}

Aase, L. (2005). Skolefagenes ulike formål - danning og nytte. I K. Børhaug, A.-B. Fenner \& L. Aase (Red.), Fagenes begrunnelser: skolens fag og arbeidsmåter i danningsperspektiv (s. 15-28). Bergen: Fagbokforlaget.

Almansa, A. (2004). El español en Dinamarca, Noruega e Islandia. El español en el mundo. Anuario del Instituto Cervantes. Centro Virtual Cervantes. Hentet fra http://cvc.cervantes.es/obref/anuario/anuario_04/almansa/default.htm

Bachmann, K. E. (2004). Læreboken i reformtider - et verktøy for endring? I G. Imsen (Red.), Det ustyrlige klasserommet: om styring, samarbeid og læringsmiljø i grunnskolen. Oslo: Universitetsforlaget.

Berge, K. L., Maagerø, E., Coppock, P. J., Halliday, M. A. K., Martin, J. R. \& Hasan, R. (1998). Å skape mening med språk: en samling artikler. Oslo: Cappelen akademisk forlag.

Carrai, D. (2009). Motivación y abandono en el aprendizaje del Español en Noruega. I: La motivación. Biblioteca Virtual redELE, spesialnummer. Hentet fra http://www.mecd.gob.es/redele/Biblioteca-Virtual/2010/NumerosEspeciales/FiapeIIICongreso.html

Casal, I. I. (1998). Diversidad cultural en el aula de E/LE: La interculturalidad como desafío y como provocación. I K. Alonso, F. M. Fernández \& M. G. Bürmann (Red.), La enseñanza del español como lengua extranjera: del pasado al futuro. Actas del VIII Congreso Internacional de ASELE (s. 463-472). Alcalá de Henares: Universidad de Alcalá.

Castagnani, T. (2009). La representación de Hispanoamérica en dos manuales de ELE de nivel avanzado. Memoria de master. Universitat de Barcelona/Universitat Pompeu Fabra. 
Christiansen, A. (2006). Kunnskapsløftet og videreutdanning i spansk. UNIPED, 3/2006, 3237.

Cuesta, I. de la. (2009). La imagen de España e Hispanoamérica en los manuales de español utilizados en la enseñanza secundaria en Suecia. Actas del II Congreso de Hispanistas y Lusitanistas Nórdicos.

Doetjes, G., \& Ryen, E. (2009). Språkvalg på ungdomsskolen. En kartlegging. Fokus på språk, 16/2009. Halden: Fremmedspråksenteret.

Eide, L. (2011). "Salsa, sol og sosial urettferdiget" - Om fremstillingen av fremmede kulturer i lærebøker i fremmedspråk, illustrert ved tekster om Cuba i lærebøker for spansk. Comunicare, 1/2011, 34-36. Halden: Fremmedspråksenteret.

Eide, L. (2012). Representasjoner av målspråksområdet i fremmedspråksfaget. En studie av Latin-Amerika i larebøker i spansk (Doktoravhandling). Bergen, Universitetet i Bergen.

Eide, L., \& Johnsen, Å. (2006). La presencia de América Latina en los métodos de E/LE en Noruega. Biblioteca Virtual redELE, spesialnummer. Hentet fra http://www.educacion.gob.es/redele/Biblioteca-Virtual/2006/NumerosEspeciales/Noviembre_Noruega.html

Eide, L., \& Johnsen, Å. (2007). Spanskfagets vilkår i skolen og i lærerutdanningen. Innlegg på Fagdidaktikk mellom skole og lærerutdanning. Første nordiske fagdidaktikkonferanse, Oslo, 15.5.2007.

Europarådet (2003). Language Education Policy Profile for Norway. Experts’ Report. Strasbourg: Council of Europe.

Fenner, A.-B. (2000). Cultural Awareness. I A.-B. Fenner \& D. Newby (Red.), Approaches to materials design in European textbooks: implementing principles of authenticity, learner autonomy, cultural awareness (s. 142-150). Strasboug: Council of Europe.

Gjørven, R., \& Trebbi, T. (2008). Fremmedspråkfaget - et fag på nye veier. I P. Arneberg \& L. G. Briseid (red.), Fag og danning: mellom individ og fellesskap (s. 111-123). Bergen: Fagbokforlaget.

Halliday, M. A. K. (1985). An introduction to functional grammar. London: Arnold.

Izquierdo, J. M. (2010). Aprender español en Noruega: por qué y para qué. Biblioteca Virtual redELE, spesialnummer. Hentet fra

http://www.mecd.gob.es/redele/Biblioteca-Virtual/2011/Numeros-

Especiales/III_CONGRESO_DE_ANPE.html

Johnsen, E. B. (1993). Textbooks in the kaleidoscope: a critical survey of literature and research on educational texts. Oslo: Scandinavian University Press.

Kunnskapsdepartementet (2006). Lœreplan i fremmedspråk. Oslo: Utdanningsdirektoratet. Hentet fra http://www.udir.no/Lareplaner/Grep/

Lindemann, B. (2008). Læring av fremmedspråk og motivasjon for språklæring etter innføringen av Kunnskapsløftet. Fokus på språk, 11/2008. Halden:

Fremmedspråksenteret.

Martin, J. R., \& White, P. R. R. (2005). The language of evaluation: appraisal in English. Basingstoke: Palgrave Macmillan.

Neuner, G. (2003). Socio-cultural interim worlds in foreign language teaching and learning. I M. Byram (Red.), Intercultural Competence (s. 15-62). Strasbourg: Council of Europe.

Nielsen, H. L. (2003). Det forpligtende kulturmøde. Sproglereren, 4/2003, 8-10.

Nygård, G. (2007). Kultur i Kunnskapsløftet - fra læereplan til læerebok (Masteroppgave). Oslo: Universitetet i Oslo.

Risager, K. (1991). Cultural References in European Textbooks: An Evaluation of Recent Tendencies. I D. Buttjes \& M. Byram (Red.), Mediating Languages and Cultures: Towards an Intercultural Theory of Foreign Language Education (s. 181-192). Clevedon: Multilingual Matters Ltd. 
Rogne, M. (2009). Læreboka - ein garantist for læreplannær undervisning? Acta Didactica Vol. 3, Nr. 1

Selander, S. (1988). Lärobokskunskap. Lund: Studentlitteratur.

Simes, S. M. (2008). -Spansk har lav status i norsk skole! Lektorbladet, 2/2008, 19-20.

Skrunes, N. (2010). Larebokforskning: en eksplorerende presentasjon med scrlig fokus på kristendomskunnskap, KRL og religion og etikk. Oslo: Abstrakt forlag.

Solfjeld, K. (2007). Andre fremmedspråk på ungdomstrinnet - med praktisk tilnærming. Fokus på språk, 1/2007. Halden: Fremmedspråksenteret.

Speitz, H., \& Lindemann, B. (2002). "Jeg valgte tysk fordi hele familien min ville det, men jeg angrer": Status for 2. fremmedspråk i norsk ungdomsskole. Notodden:

Telemarksforsking.

Utdanningsdirektoratet. (2005). Kartlegging av læremidler og læremiddelpraksis. Oslo.

Ziehe, T. (2001). De personlige livsverdeners dominans. Ændret ungdomsmentalitet og skolens anstrengelser. Uddannelse, 10.

${ }^{1}$ Se http://www.anpenorge.no/wordpress/estadisticas/ for statistikker over antall elever på hvert språkfag.

${ }^{2}$ For å undervise i spansk på ungdomstrinnet kreves det 30 studiepoeng i faget, det vil si et halvt års fulltids- studium, mens man i videregående skole krever 60 studiepoeng.

${ }^{3}$ Ana Almansa er tidligere rådgiver ved den spanske ambassaden i København.

${ }^{4}$ I metodedelen er det et poeng å presisere at det er "tekstbøkene” jeg analyserer, men i resten av artikkelen bruker jeg betegnelsen "lærebøker”.

${ }^{5}$ Forlagene Cappelen og Damm fusjonerte i 2007.

${ }_{i}^{6}$ Vale! (Cappelen Damm), Caminando (Gyldendal) og Chicos, chicas (Aschehoug).

${ }^{7}$ Jeg har valgt å se bort fra skjønnlitterære tekster, som gjerne kan ha sitt opphav i Latin-Amerika, men som samtidig kan omhandle helt andre temaer.

${ }^{8}$ For en utførlig presentasjon av analysemodellen, se Eide (2012, s. 92-108)

${ }^{9}$ Tekstene jeg analyserer i denne artikkelen er på spansk. Oversettelsene av originaltekstene fra spansk til norsk er mine egne.

${ }^{10}$ For en mer utfyllende presentasjon av hvordan Cuba blir fremstilt i norske lærebøker i spansk, se Eide (2011). 